\title{
OPTIMIZATION OF SLAUGHTER AGE OF JAMUNA BASIN LAMB BASED ON CARCASS TRAITS AND MEAT QUALITY
}

\author{
M.A. Hossain ${ }^{1}$, M.M. Rahman ${ }^{1}$, M.W. Rahman ${ }^{2}$, M.M. Hossain ${ }^{1}$ \\ and M.A. Hashem ${ }^{1^{*}}$ \\ ${ }^{1}$ Department of Animal Science \\ ${ }^{2}$ Department of Rural Sociology \\ Bangladesh Agricultural University, Mymensingh, Bangladesh
}

\begin{abstract}
The aim of this study was to identify optimum slaughter age on carcass traits and meat quality of Jamuna basin lambs. Thirty lambs were divided into three age groups like $T_{1}$ (6 months), $T_{2}$ (9 months) and $T_{3}$ (12 months) having ten lambs of each treatment. Parameters studied were carcass traits, proximate component (DM, CP, EE, and Ash), physicochemical (Ultimate $\mathrm{pH}$, cooked $\mathrm{pH}$, cooking loss, drip loss, water holding capacity-WHC), sensory attributes (color, flavor, tenderness, juiciness, overall acceptability) and instrumental color values $\left(\mathrm{L}^{*}, \mathrm{a}^{*}\right.$ and $\left.b^{*}\right)$. Hot carcass weight and dressing $\%$ were found significantly $(p<0.001)$ higher in $T_{3}$ than $T_{1}$ and $T_{2}$ treatments. Edible by products namely viscera, head, leg, pluck, neck, shoulder, rack, loin, kidney, heart, liver, lungs and shank from three treatments were found significant effect $(p<0.001)$. Inedible by products viz. blood, skin and spleen were found significantly higher $(p<0.001)$ with the advancement of age. Dry matter $(D M)$ of $T_{2}$ and $T_{3}$ were found significantly lower $(p<0.001)$ than $T_{1}$ treatment. Crude protein $(\mathrm{CP})$ and ether extract (EE) were significantly increased $(p<0.001)$ of advancement of age of lambs. Drip loss of $T_{2}$ was found significantly lower and WHC of $\mathrm{T}_{2}$ was significantly $(p<0.001)$ higher than other two treatments. Cooking loss and ultimate $\mathrm{pH}$ of $\mathrm{T}_{3}$ were significantly $(p<0.001)$ lower than other two treatments. Color, tenderness, juiciness and overall acceptability were significantly differed $(p<0.001)$ and flavor was significantly differed $(p<0.001)$. The instrumental color values $L^{*}$ decreased whereas $a^{*}$ and $b^{*}$ and chroma values were significantly $(p<0.05)$ increased with the advancement of age of lambs. The saturation index was significantly $(p<0.001)$ higher in 6 - and 12-months age than 9 months of age. It is revealed from the study that 12 months of slaughter age showed better in terms of productive
\end{abstract}

\footnotetext{
* Corresponding Author: hashem_as@bau.edu.bd
} 
and meat quality traits. Therefore, 12 months of age may be recommended as optimum slaughter age for Jamuna basin lambs.

Keywords: Carcass traits, Jamuna basin lambs, Physicochemical quality, Sensory traits, Slaughter age

\section{INTRODUCTION}

Sheep is one of the important small ruminant species which is widely distributed throughout the world providing meat and wool. This species is widely adapted to different climatic condition and is found all livestock production system (Berihulay, 2019). Good nutrition and management play a significant role on sheep production (Sarker et al., 2017; Hossain et al., 2018a; Hossain et al., 2021). During last twelve years sheep population increased 2.5 times, with annual growth rate of 5\% (Rana et al., 2014; Murshed et al., 2014). Lamb is softer than chevon which easily digests (Haque et al., 2020). Sheep are tolerant to disease in the humid and sub-humid tropics. Sheep rearing is directly involved with poverty alleviation, employment generation and good quality nutrients supply. Most of the sheep are indigenous, with few crossbreds and are capable of bi-annual lambing and multiple births (Rashid et al., 2013; Hossain et al., 2018b). The characteristics of Jamuna basin lamb is small body size (male-18.25 kg, female-15.22 kg) which is widely distributed at Tangail, Sirajganj, Gaibandha, Sherpur, Jamalpur, Mymensingh and Dhaka specially, both sides of Jamuna River in Bangladesh. It has creamy white wool all over the body but head and belly contain black wool. Less wool found in legs and belly (Hashem et al., 2020). It is a prolific variety of Bangladeshi lamb, female give birth twin lamb in most of the cases. The dietary nutrients usually energy and protein are the major important factors affecting meat production in goats and sheep (Sultana et al., 2010). Jamuna basin lambs achieved average daily gain (ADG) 46-55g in active growing phase and marketed for slaughter at 9-12 months of age weighing about $15-18 \mathrm{~kg}$ (Hashem et al., 2020). The body weight information can be used in determining the value of animals and efficiency of rearing (Sun et al., 2020). Sheep farming has been also significant in the development and economic growth in different developed countries. It provides a significant amount of mutton/ lamb in local meat market of Bangladesh as well as improves the rural livelihood. The color of mutton has a critical influence on consumer purchasing decisions (Mancini and Hunt, 2005). It is as an indicator of quality and freshness for consumers. Consumers treated red meat as fresher and higher quality, whereas pale, discolored, or darker meat is treated by consumers as poor quality (Hashem et al., 2013). The feeding habits of meat consumers were characterized by important changes last decade. They identify healthier foods and higher demands of quality products have led part of the market niche to consume meats of better nutritional and sensory quality (Costa et al., 2011). The lamb meat is the best options for consumers which are willing to pay for a high quality product; however, it fails in gaining market space due to the lack of 
standardization and quality when it reaches to the consumer (Cirne et al., 2018). At present, Department of Livestock Services (DLS) is given special attention for sheep rising and farmers are now interested in sheep farming for lamb production. Only limited research is reported slaughter age determination in beef cattle in Bangladesh (Ali et al., 2013; Hosain et al., 2015). It is recognized that after certain age, growth rate of lamb is reduced, which is not economical to lamb producers. So, it is essential to establish an appropriate age to perform better response and avoid expensive fat deposition and bad flavor in the carcass for the attraction of consumer and ensure real market price. But no research works were carried out yet of determining optimum slaughter age on carcass characteristics, proximate, physicochemical traits, sensory attributes, and instrumental color values for village level lamb farming condition in Bangladesh. Therefore, the present study was conducted to identify the optimum slaughter age on carcass traits and meat quality under village level farming condition of Jamuna basin lambs.

\section{MATERIALS AND METHODS}

\section{Experimental animals and management}

The study was carried out for three months during October 2019 to December 2019. Thirty Jamuna basin lambs were selected on the basis of different age, same management, feeding and vaccination with three treatment groups: $\mathrm{T}_{1}$ (6 months), and $\mathrm{T}_{2}$ (9 months) and $\mathrm{T}_{3}$ (12 months) having ten animals per group. The diet was supplied uniformly for all animals. Green grass and fresh water were supplied ad libitum with $1.5 \%$ concentrate feed containing $18 \% \mathrm{CP}$ and $12 \mathrm{MJME} / \mathrm{kg}$ DM. Diets were formulated (Table 1) and provided to the lambs twice a day (Morning and evening).

Table 1. Feed ingredient (\%) of concentrate supplementation

\begin{tabular}{ll}
\hline Item & Amount \% \\
\hline Wheat crushed & 68.00 \\
Soybean meal & 30.00 \\
Di-calcium phosphate (DCP) & 0.50 \\
Vitamin-mineral premix & 0.50 \\
Common salt & 1.00 \\
\hline
\end{tabular}

\section{Slaughter procedure and carcass sampling}

At the end of the growth and feeding trial, thirty lambs from ten each of the treatments were slaughtered. All the selected animals were fasted for $24 \mathrm{~h}$ and slaughtered according to the "Halal" method. The fasted live weights of the animals were recorded prior slaughtering, and individual hot carcass weights were recorded immediately after evisceration. Non-carcass components (skin, head, liver, spleen, 
lung, shank, heart, kidneys, and viscera) were removed and measured weight. The digesta content of the stomach and intestinal tract were removed, and the empty tract was washed and weighed. Dressing\% was calculated as hot carcass weight relative to fasted body weight. The 100-120g sample was taken from Longissimus dorsi (LD) area for proximate component, physicochemical traits, sensory attributes and instrumental color values analyses. Different parameters like live weight gain (LWG), carcass characteristics and meat quality of lambs were recorded. Live weight of each lamb was recorded at the onset of the trial and later on monthly basis. Concentrate feed of known weight was offered daily.

\section{Proximate components}

The proximate components regarding to dry matter (DM), ether extract (EE), crude protein (CP) and ash was carried out according to AOAC (2005).

\section{Sensory evaluation}

Different sensory attributes were examined in this study. Each meat sample was evaluated by a trained 8-member panel. The sensory questionnaires measured intensity on a 5- point balanced semantic scale for the attributes viz. color, flavor, tenderness, juiciness, and overall acceptability. Eight training sessions were held to familiarize the judges with the attributes to be evaluated and the scale to be used (Jahan et al., 2018: Saba et al., 2018). Prior to sample evaluation, all panelists participated in orientation sessions to familiarize with the scale attributes (color, flavor, juiciness, tenderness, overall acceptability) of meat using intensity scale. All samples were served in the petri dishes.

\section{Physicochemical properties measurement}

\section{Drip loss}

Drip loss was measured following the procedure of Rahman et al. (2020). Approximately $20 \mathrm{~g}$ meat samples were cut from the collected sample, immediately weighed and hung in a covered plastic bag for 24 hours at $4^{\circ} \mathrm{C}$. After $24 \mathrm{~h}$, samples were removed, gently blotted dry and reweighed; drip loss was calculated as the percentage of weight loss. The difference in weight expressed to the drip loss and showed as the percentage of the initial weight.

$$
\text { Drip loss }(\%)=\frac{\text { (Weight of sample }- \text { weight after } 24 \text { hours chilling) }}{\text { Weight of sample }} \times 100
$$

\section{Cooking loss}

Cooking loss was measured according to Rahman et al. (2020). For the determination of cooking loss at $24 \mathrm{~h}$ post-mortem, approximately $20 \mathrm{~g}$ sample was cut perpendicularly to the fiber orientation from the meat sample. The thickness of the samples was standardized to approximately $2 \mathrm{~cm}$. The samples were then placed in a plastic bag and immersed in boiling water with the sealed bag opening extending above the water surface (Rahman et al., 2020). The samples were cooked to an 
internal temperature of $71^{\circ} \mathrm{C}$ for 30 minutes, whereas the temperature was recorded using a digital food grade thermometer. The meat samples were taken out and then cooled. After cooling the samples to room temperature, moisture was blotted, samples were weighed, and the cooking loss expressed as weight loss during cooking relative to the initial weight of the sample. The differences in weight before and after cooking were used to determine cooking loss (\%).

Cooking loss $(\%)=\frac{\left(\text { Weight of sample }- \text { weight after cooking at } 71^{\circ} \mathrm{C} \text { for } 30 \mathrm{~min}\right)}{\text { Weight of sample }} \times 100$

\section{Raw pH measurement}

Meat $\mathrm{pH}$ value was measured $24 \mathrm{~h}$ after slaughter (ultimate $\mathrm{pH}$ ) using a $\mathrm{pH}$ meter. The $\mathrm{pH}$ was measured by inserting electrode at three different points of the meat which was calibrated prior to use at $\mathrm{pH} 7.0$ by $\mathrm{pH}$ meter (Hanna HI 99163). Triplicate measurements at $1 \mathrm{~cm}$ depth on the medial portion of meat were averaged.

\section{Cooked pH}

The samples were cooked to an internal temperature of $71^{\circ} \mathrm{C}$ for 30 minutes. Then the muscle samples were taken out, after that cooled at room temperature. After cooling sample $\mathrm{pH}$ was measured as the same way of raw sample.

\section{Water holding capacity (WHC)}

The WHC was measured according to the methodology of Choi et al. (2018). Thawed samples (1 g each) were wrapped in absorbent cotton and placed in a $1.5 \mathrm{ml}$ centrifuge tube. The tubes with samples were centrifuged in a centrifuge separator (H1650-W Table top high speed micro centrifuge) at 10,000 RPM for $10 \mathrm{~min}$ at $4^{\circ} \mathrm{C}$ temperature, following which the samples were weighed. The WHC of the sample is expressed as the ratio of the sample weight after centrifugation to the initial sample weight, using the following formula:

Water holding capacity $(\%)=\frac{\text { (Weight of sample after centrifugation) }}{(\text { Weight of sample before centrifugation })} \times 100$

\section{Instrumental color measurement}

Instrumental color measurement was carried out on meat from longissimus muscle. Color was measured at $24 \mathrm{~h}$ post-slaughter using Konica Minolta Chroma Meter (CR 410, Konica Minolta Sensing, Inc., Osaka, Japan), a Miniscan Spectro colorimeter programmed with the CIE Lab, (International Commission on Illumination) L*, a*, and $b^{*}$ system, where $L^{*}$ represents lightness, $a^{*}$ redness and $b^{*}$ yellowness (CIELAB, 2014). The analysis was carried out on the medial surface (bone side) of the meat at $24 \mathrm{~h}$ post-mortem (Rahman et al., 2020). The colorimeter was calibrated using the specific whiteboard before measurement began. Each value was an average of three measurements from an area of the meat between $4-5 \mathrm{~cm}^{2}$ to get a representative evaluation of the samples. The L* value is the lightness component, 
which ranges from 0 to 100 (from black to white); $a *$ and $b *$ both range from -60 to +60 with $a *$ ranging from green if negative to red if positive and $b *$ ranging from blue if negative to yellow if positive.

\section{Statistical analysis}

Data were analyzed by CRD with SAS software. DMRT test was used to determine the significance of differences among treatments means.

\section{RESUTS AND DISCUSSION}

\section{Effect of different slaughter ages on carcass traits of Jamuna basin lambs}

The initial and final mean body weight of lambs were 4.64, 9.78; 7.90, 13.25, and $10.57,15.80$ in three treatments, respectively (Table 1) had a significant effect ( $p>0.001$ ). The ADG was $57.39,59.80$ and $58.15 \mathrm{~g} / \mathrm{d}$ in all treatments, respectively which was non-significant ( $\mathrm{p}>0.001$ ). Hashem et al., (2020) showed ADG at 6, 9 and 12 months aged lambs were $54.75,53.59$ and $48.81 \mathrm{~g} / \mathrm{d}$ which were not similar to the present study. Hot carcass $(\mathrm{kg})$ and dressing \% were found significantly $(\mathrm{p}>0.001)$ increased with the increasing of age $(4.35,44.36 ; 6.00,45.29$, and $7.6,48.15)$. These results differed to the findings of Claffey et al., (2018) where they stated that hot carcass $(\mathrm{kg})$ and dressing \% were 25.7 and 47.9 of 12 months aged lambs. Similar result was found by Polidori et al. (2017). Worku et al. (2020) found similar significant effect of hot carcass and dressing \% in their study. Dressing percentage is both yielding and value determining factor as an important parameter in the assessment performance of meat producing lambs. The mean of viscera and head were significantly decreased in all treatments whereas leg was significantly $(\mathrm{p}<0.001)$ increased in $T_{1}$ and $T_{2}$ except $T_{3}$ treatment with the increasing of age. Pluck was significantly increased in $T_{1}$ and $T_{2}$ except $T_{3}$ with the increasing of age had a significant effect $(\mathrm{p}<0.001)$. Blood of present study was significantly $(\mathrm{p}<0.001)$ increased whereas skin significantly decreased in $T_{3}$ compared to $T_{1}$ and $T_{2}$ treatments with the increasing of age. These results were supported by Huque et al. (2007). Rack, kidney, liver, lung and spleen were found significantly increased with the increasing of age except loin and heart in $\mathrm{T}_{2}$. Rack and loin were not similar but liver and kidney of the present study were higher to the findings of Sultana et al. (2010). Spleen of the present study was almost similar but shank was differed to Sultana et al. (2010), where they showed that shank \% was 1.2, 1.8 and 2.2 at 6, 9 and 12 months of age, respectively. Moniruzzaman et al. (2002) stated that slaughter age had a significant effect on dressing percentage and meat quality. 
Table 1. Effect of different slaughter ages on carcass traits of Jamuna basin lambs

\begin{tabular}{|c|c|c|c|c|}
\hline \multirow{2}{*}{ Parameters } & \multicolumn{3}{|c|}{ Treatment $($ Mean \pm SE) } & \multirow[t]{2}{*}{$\begin{array}{c}\text { Level of } \\
\text { significance }\end{array}$} \\
\hline & $\mathrm{T}_{1}$ & $\mathrm{~T}_{2}$ & $\mathrm{~T}_{3}$ & \\
\hline Initial body wt. (kg) & $4.64^{\mathrm{c}} \pm 0.10$ & $7.90^{\mathrm{b}} \pm 0.09$ & $10.57^{\mathrm{a}} \pm 0.21$ & $<.0001$ \\
\hline Final body wt. (kg) & $9.78^{\mathrm{c}} \pm 0.08$ & $13.25^{\mathrm{b}} \pm 0.01$ & $15.80^{\mathrm{a}} \pm 0.23$ & $<.0001$ \\
\hline ADG $(g)$ & $57.39^{\mathrm{a}} \pm 1.14$ & $59.80^{\mathrm{a}} \pm 1.48$ & $58.15^{\mathrm{a}} \pm 1.75$ & NS \\
\hline \multicolumn{5}{|l|}{$\%$ Of live weight basis } \\
\hline Hot carcass wt. (kg) & $4.35^{\mathrm{c}} \pm 1.14$ & $6.00^{\mathrm{b}} \pm 0.05$ & $7.6^{\mathrm{a}} \pm 0.21$ & $<.0001$ \\
\hline Dressing wt. & $44.36^{\mathrm{b}} \pm 0.04$ & $45.29^{b} \pm 0.01$ & $48.15^{\mathrm{a}} \pm .86$ & $<.0001$ \\
\hline Blood wt. & $3.26^{\mathrm{b}} \pm 0.02$ & $3.34^{\mathrm{b}} \pm 0.03$ & $4.18^{\mathrm{a}} \pm 0.20$ & $<.0001$ \\
\hline Skin wt. & $12.62^{\mathrm{a}} \pm 0.10$ & $12.74^{\mathrm{a}} \pm 0.10$ & $9.79^{\mathrm{b}} \pm 0.52$ & $<.0001$ \\
\hline Viscera wt. & $23.43^{\mathrm{a}} \pm 0.39$ & $22.76^{\mathrm{a}} \pm 0.17$ & $14.36^{\mathrm{b}} \pm 0.21$ & $<.0001$ \\
\hline Head wt. & $8.67^{\mathrm{a}} \pm 0.07$ & $6.30^{\mathrm{b}} \pm 0.04$ & $5.52^{\mathrm{c}} \pm 0.08$ & $<.0001$ \\
\hline Leg wt. & $12.22^{\mathrm{b}} \pm 0.10$ & $13.50^{\mathrm{a}} \pm 0.10$ & $10.34^{\mathrm{c}} \pm 0.15$ & $<.0001$ \\
\hline $\begin{array}{l}\text { Half carcass wt. } \\
(\mathrm{kg})\end{array}$ & $2.18^{\mathrm{b}} \pm 0.09$ & $3.00^{\mathrm{b}} \pm 0.08$ & $3.8^{\mathrm{a}} \pm 0.43$ & $<.0001$ \\
\hline Pluck wt. & $5.30^{\mathrm{c}} \pm 0.04$ & $7.18^{\mathrm{a}} \pm 0.05$ & $6.87^{\mathrm{b}} \pm 0.16$ & $<.0001$ \\
\hline Neck wt. & $3.93^{\mathrm{b}} \pm 0.03$ & $5.32^{\mathrm{a}} \pm 0.04$ & $3.64^{\mathrm{c}} \pm 0.05$ & $<.0001$ \\
\hline Shoulder wt. & $8.38^{\mathrm{c}} \pm 0.07$ & $11.35^{\mathrm{a}} \pm 0.08$ & $8.66^{\mathrm{b}} \pm 0.13$ & $<.0001$ \\
\hline Rack wt. & $6.05^{\mathrm{c}} \pm 0.05$ & $8.20^{\mathrm{b}} \pm 0.06$ & $9.79^{\mathrm{a}} \pm 0.15$ & $<.0001$ \\
\hline Loin wt. & $3.56^{\mathrm{b}} \pm 0.01$ & $3.31^{\mathrm{c}} \pm 0.02$ & $4.42^{\mathrm{a}} \pm 0.04$ & $<.0001$ \\
\hline Shank wt. & $2.82^{\mathrm{b}} \pm 0.03$ & $3.82^{\mathrm{a}} \pm 0.03$ & $2.08^{\mathrm{c}} \pm 0.03$ & $<.0001$ \\
\hline \multicolumn{5}{|c|}{$\%$ Of hot carcass weight basis } \\
\hline Kidney wt. & $0.48^{\mathrm{c}} \pm 0.00$ & $0.67^{\mathrm{b}} \pm 0.01$ & $1.74^{\mathrm{a}} \pm 0.05$ & $<.0001$ \\
\hline Liver wt. & $2.02^{\mathrm{c}} \pm 0.02$ & $2.78^{\mathrm{b}} \pm 0.02$ & $3.87^{\mathrm{a}} \pm 0.11$ & $<.0001$ \\
\hline Heart wt. & $0.62^{\mathrm{b}} \pm 0.01$ & $0.85^{\mathrm{a}} \pm 0.01$ & $0.82^{\mathrm{a}} \pm 0.02$ & $<.0001$ \\
\hline Lung wt. & $1.12^{\mathrm{b}} \pm 0.01$ & $1.55^{\mathrm{a}} \pm 0.01$ & $1.63^{\mathrm{a}} \pm 0.05$ & $<.0001$ \\
\hline Spleen wt. & $0.20^{\mathrm{c}} \pm 0.00$ & $0.29^{\mathrm{b}} \pm 0.00$ & $0.74^{\mathrm{a}} \pm 0.02$ & $<.0001$ \\
\hline
\end{tabular}

Superscripts of the same letter in each row did not differ significant $(\mathrm{p}>0.05), \mathrm{T}_{1}=$ Six-month age, $\mathrm{T}_{2}=$ Nine month age and $\mathrm{T}_{3}=$ Twelve month age.

Effect of different slaughter ages on proximate components of Jamuna basin lambs

Table 2 shows that DM, CP and EE were found 24.72, 24.26, 27.54 and 15.91, 18.12, 24.05 and $1.45,1.77,3.51$ in $\mathrm{T}_{1}, \mathrm{~T}_{2}$ and $\mathrm{T}_{3}$ treatments, respectively which was 
significantly differed $(p<0.001)$. The $\mathrm{DM}, \mathrm{CP}$ and $\mathrm{EE} \%$ in $\mathrm{T}_{3}$ were found significantly $(p<0.001)$ higher compared to $T_{1}$ and $T_{2}$ treatments. From the study, lamb meat of older lambs showed a significant higher amount of fat and protein which was supported by Polidori et al. (2017). The DM and EE of 12 month age of the present study was supported by Sultana et al., (2010) and Rajkumar et al. (2017) where they found higher DM and EE values in their study. The CP was estimated purely on fresh meat basis, where moisture \% was higher compared to 12 months age group. Therefore, resulting in lower CP at 6 and 9 months aged lamb than 12 months age. The CP \% was not supported to the findings of Worku et al. (2020). Ash \% in $\mathrm{T}_{3}$ was found lower than that of $\mathrm{T}_{1}$ and $\mathrm{T}_{2}$ treatments which was non-significant ( $p>0.05$ ). These findings were not supported to Gashu et al. (2017) where they showed higher percentage of ash at 12 months aged lamb in their study.

Table 2. Effect of different slaughter ages on proximate components of Jamuna basin lambs

\begin{tabular}{lllll}
\hline & \multicolumn{3}{c}{ Treatment (Mean \pm SE) } & \multicolumn{1}{c}{$\begin{array}{c}\text { Level of } \\
\text { significance }\end{array}$} \\
\cline { 2 - 5 } & \multicolumn{1}{c}{$\mathrm{T}_{1}$} & \multicolumn{1}{c}{$\mathrm{T}_{2}$} & \multicolumn{1}{c}{$\mathrm{T}_{3}$} \\
$\mathrm{nyyyy}$ DM & $24.72^{\mathrm{b}} \pm 0.10$ & $24.26^{\mathrm{b}} \pm 0.27$ & $27.54^{\mathrm{a}} \pm 0.12$ & $<.0001$ \\
$\mathrm{CP}$ & $15.91^{\mathrm{c}} \pm 0.11$ & $18.12^{\mathrm{b}} \pm 0.10$ & $24.05^{\mathrm{a}} \pm 0.07$ & $<.0001$ \\
$\mathrm{EE}$ & $1.45^{\mathrm{c}} \pm 0.05$ & $1.77^{\mathrm{b}} \pm 0.10$ & $3.51^{\mathrm{a}} \pm 0.15$ & $<.0001$ \\
Ash & $1.01^{\mathrm{a}} \pm 0.03$ & $1.00^{\mathrm{a}} \pm 0.01$ & $0.96^{\mathrm{a}} \pm 0.04$ & $\mathrm{NS}$ \\
\hline
\end{tabular}

Superscripts of the same letter in each row did not differ significant ( $\mathrm{p}>0.05), \mathrm{T}_{1}=$ Six month age, $\mathrm{T}_{2}=$ Nine month age and $\mathrm{T}_{3}=$ Twelve month age, $\mathrm{DM}=$ Dry matter, $\mathrm{CP}=$ Crude protein, $\mathrm{EE}=$ Ether extract.

\section{Effect of different slaughter ages on physicochemical traits of Jamuna basin lambs}

Table 3 shows that ultimate $\mathrm{pH}$ and cooked $\mathrm{pH}$ were found $6.29,6.57 ; 6.09,6.50$ and $5.95,6.46$ in all treatments, respectively in which cooked $\mathrm{pH}$ was significantly differed $(\mathrm{p}<0.05)$. Drip loss and coking loss \% were found 5.61, 33.97; 3.09, 33.64 and 3.16, 34.33 in three treatments, respectively which was significantly differed $(\mathrm{p}<0.001)$. Drip loss of the present study was not supported by Watanabe et al. (2018) where they showed lower drip loss $(2.89 \%)$. The WHC \% was found 84.26, 91.50 and 89.23 in three treatments, respectively which was significantly differed $(\mathrm{p}<0.001)$. Drip loss $\%$ was found acceptable ranges $(0-4 \%)$ in $\mathrm{T}_{2}$ and $\mathrm{T}_{3}$ compared to $\mathrm{T}_{1}$ treatment. Drip loss is considered to be very important for palatability and the overall quality and acceptability meat to consumers. Ultimate $\mathrm{pH}$ was found optimum ranges (5.5-5.9) in $\mathrm{T}_{3}$ compared to $\mathrm{T}_{1}$ and $\mathrm{T}_{2}$ treatments. The ultimate $\mathrm{pH}$ from present study $\left(\mathrm{T}_{3}\right)$ was supported and cooking loss differed to the findings of Watanabe et al. (2018). Higher ultimate $\mathrm{pH}$ was found in $\mathrm{T}_{1}$ and $\mathrm{T}_{2}$ treatments. The 
causes of higher $\mathrm{pH}$ might be due to withdrawal of feed for longer time, as well as transportation stress also occurred due to transport the lambs from a distant place for slaughtering. These feed and transportation stress will decrease the amount of glycogen present in muscle at slaughter; thereby resulting a higher ultimate $\mathrm{pH}$. These differences of $\mathrm{pH}$ will be also occurred between and within different breeds. Due to increasing age 6 and 9 months are more susceptible than 12 months age. The lambs were transported about $90 \mathrm{~km}$ from Sherpur to Bangladesh Agricultural University (BAU) Market before slaughtered. Due to transportation stress glycogen has already been utilized. After keeping the meat sample preserved for $24 \mathrm{~h}$ at $4^{\circ} \mathrm{C}$, enough lactic acid could not be produced, thereby resulting higher ultimate $\mathrm{pH}$ was found in 6 and 9 months age of lambs. It is assumed that lower the age the $\mathrm{pH}$ was higher. The WHC is the ability of meat to hold all or part of its water, and one of the most important traits of meat quality. The WHC\% was significantly $((\mathrm{p}<0.00)$ higher in $\mathrm{T}_{2}$ than that of $\mathrm{T}_{1}$ and $\mathrm{T}_{3}$ treatments. The WHC and cooking loss of the present study differed to the findings of Cirne et al. (2018) where they stated that WHC and cooking loss were 58.3 and $41.95 \%$, respectively.

Table 3. Effect of different slaughter ages on physicochemical traits of Jamuna basin lambs

\begin{tabular}{lllll}
\hline \multirow{2}{*}{ Parameters } & \multicolumn{2}{c}{ Treatment (Mean $\pm \mathrm{SE})$} & \multicolumn{1}{c}{$\begin{array}{c}\text { Level of } \\
\text { significance }\end{array}$} \\
\cline { 2 - 5 } Drip loss \% & \multicolumn{1}{c}{$\mathrm{T}_{1}$} & \multicolumn{1}{c}{$\mathrm{T}_{2}$} & \multicolumn{1}{c}{$\mathrm{T}_{3}$} & \\
\cline { 2 - 5 } Cooking loss \% & $5.61^{\mathrm{a}} \pm 0.12$ & $3.09^{\mathrm{b}} \pm 0.03$ & $3.16^{\mathrm{b}} \pm 0.02$ & $<.0001$ \\
Ultimate pH & $6.97^{\mathrm{c}} \pm 0.02$ & $33.64^{\mathrm{b}} \pm 0.02$ & $34.33^{\mathrm{a}} \pm 0.08$ & $<.0001$ \\
Cooked pH & $6.57^{\mathrm{a}} \pm 0.03$ & $6.09^{\mathrm{b}} \pm 0.07$ & $5.95^{\mathrm{b}} \pm 0.07$ & 0.0020 \\
WHC \% & $84.26^{\mathrm{c}} \pm 0.09$ & $6.50^{\mathrm{a}} \pm 0.02$ & $6.46^{\mathrm{a}} \pm 0.06$ & $\mathrm{NS}$ \\
\hline
\end{tabular}

Superscripts of the same letter in each row did not differ significant $(p>0.05), T_{1}=$ Six-month age, $T_{2}=$ Nine month age and $\mathrm{T}_{3}=$ Twelve month age, $\mathrm{WHC}=$ Water holding capacity.

\section{Effect of different slaughter ages on sensory attributes of Jamuna basin lambs}

Sensory attributes is one of the important criteria of meat quality indicators estimated by the sense organ of eye, nose, mouth and taste bud of tongue. Color, flavor, tenderness, juiciness and overall acceptability were found variation from panel member to member during evaluation of meat quality. From Table 4, color and flavor were $4.10,4.53 ; 4.69,4.77$, and 4.76, 4.84 in $\mathrm{T}_{1}, \mathrm{~T}_{2}$ and $\mathrm{T}_{3}$ treatments, respectively in which color and flavor were significantly differed $(\mathrm{p}<0.001$ and $\mathrm{p}<0.05)$. Tenderness, juiciness and overall acceptability were found $4.37,4.25,4.32 ; 4.80,4.78,4.76$, and $4.84,4.82,4.81$ in three treatments, respectively which was significantly differed $(\mathrm{p}<0.001)$. Color and flavor were found higher in $\mathrm{T}_{3}$ treatment compared to $\mathrm{T}_{1}$ and $\mathrm{T}_{2}$ 
treatments. Tenderness and juiciness treatment were found higher in $\mathrm{T}_{3}$ compared to $\mathrm{T}_{1}$ and $\mathrm{T}_{2}$ treatments. Overall acceptability was found higher in $\mathrm{T}_{3}$ treatment compared to $T_{1}$ and $T_{2}$ treatments. Color, flavor, tenderness and juiciness were increased with the increasing age of lambs. Overall acceptability increased with the increasing of age. Tenderness, juiciness, flavor intensity and overall acceptability increased until 19 months of age (Kopuzlu et al., 2018) which was similar to the present study. Pethick et al. (2005) reported that there was no difference in the result of the tenderness and consumer tenderness on 12 months old lambs and 22 months old yearlings of Merino breeds. This result did not support to the present study.

Table 4. Effect of different slaughter ages on sensory attributes of Jamuna basin lambs

\begin{tabular}{lcccc}
\hline \multirow{2}{*}{\multicolumn{1}{c}{ Parameters }} & \multicolumn{3}{c}{ Treatment (Mean $\pm \mathrm{SE}$ ) } & \multicolumn{1}{c}{$\begin{array}{c}\text { Level of } \\
\text { significance }\end{array}$} \\
\cline { 2 - 5 } & \multicolumn{1}{c}{$\mathrm{T}_{1}$} & $\mathrm{~T}_{2}$ & $\mathrm{~T}_{3}$ & \\
\cline { 2 - 5 } Color & $4.10^{\mathrm{b}} \pm 0.07$ & $4.69^{\mathrm{a}} \pm 0.05$ & $4.76^{\mathrm{a}} \pm 0.04$ & $<.0001$ \\
Flavor & $4.53^{\mathrm{b}} \pm 0.10$ & $4.77^{\mathrm{a}} \pm 0.05$ & $4.84^{\mathrm{a}} \pm 0.03$ & 0.0118 \\
Tenderness & $4.37^{\mathrm{b}} \pm 0.09$ & $4.80^{\mathrm{a}} \pm 0.05$ & $4.84^{\mathrm{a}} \pm 0.03$ & $<.0001$ \\
Juiciness & $4.25^{\mathrm{b}} \pm 0.06$ & $4.78^{\mathrm{a}} \pm 0.05$ & $4.82^{\mathrm{a}} \pm 0.03$ & $<.0001$ \\
Overall acceptability & $4.32^{\mathrm{b}} \pm 0.04$ & $4.76^{\mathrm{a}} \pm 0.04$ & $4.81^{\mathrm{a}} \pm 0.03$ & $<.0001$ \\
\hline
\end{tabular}

Superscripts of the same letter in each row did not differ significant $(\mathrm{p}>0.05), \mathrm{T}_{1}=$ Six month age, $\mathrm{T}_{2}=$ Nine month age and $\mathrm{T}_{3}=$ Twelve month age.

\section{Effect of different slaughter ages on instrumental color values of Jamuna basin} lambs

Table 5 shows that $\mathrm{L}^{*}$, a* and $\mathrm{b}^{*}$ values were found $46.54,13.84,9.07 ; 44.31,14.14$, 11.34 , and $41.13,18.08,12.47$ in three treatments, respectively which was significantly $(\mathrm{p}<0.05)$ differed. The meat color is the qualitative trait that most influences the choice of consumer to purchase or reject the product. The $a^{*}$ and $b^{*}$ value were found significantly $(0.05)$ higher in $T_{3}$ compared to $T_{1}$ and $T_{2}$ treatments. The $L^{*}$ value in $T_{3}$ was found significantly $(p<0.05)$ lower than $T_{1}$ and $T_{2}$ treatments. The $a^{*}$ and $b^{*}$ value significantly $(\mathrm{p}<0.05)$ increased with increasing the age of lambs. Polidori et al. (2017) stated that $\mathrm{L}^{*}$ and $\mathrm{b}^{*}$ value was decreased and $\mathrm{a}^{*}$ value increased with increasing the age. These findings ( $\mathrm{L}^{*}$ and $\mathrm{b}^{*}$ value) were not in accordance with the present study but the trend of $a^{*}$ value in their findings supported to the present study. Hue angle from 6 months aged lambs had significantly higher $(\mathrm{p}<0.001)$ than other two groups. The 12 months lambs had significantly higher $(\mathrm{p}<0.001)$ saturation index $(\mathrm{SI})$ value than that of 6 and 9 months aged lambs which indicates more color intensity. This result was similar to Kopuzlu et al. (2018) where they stated that SI value increased with the increasing of age 
Table 5. Effect of different slaughter ages on instrumental color values of Jamuna basin lambs

\begin{tabular}{llccl}
\hline \multirow{2}{*}{ Parameters } & \multicolumn{2}{c}{ Treatment $($ Mean \pm SE) } & \multicolumn{1}{c}{$\begin{array}{c}\text { Level of } \\
\text { significance }\end{array}$} \\
\cline { 2 - 5 } $\mathrm{L}^{*}$ & \multicolumn{1}{c}{$\mathrm{T}_{1}$} & $\mathrm{~T}_{2}$ & $\mathrm{~T}_{3}$ & \\
\cline { 2 - 5 } & $46.54^{\mathrm{a}} \pm 0.36$ & $44.31^{\mathrm{a}} \pm 2.51$ & $41.13^{\mathrm{b}} \pm 0.75$ & $<0.0003$ \\
$\mathrm{a}^{*}$ & $13.84^{\mathrm{b}} \pm 0.34$ & $14.14^{\mathrm{b}} \pm 0.20$ & $18.08^{\mathrm{a}} \pm 1.06$ & $<0.0001$ \\
$\mathrm{~b}^{*}$ & $9.07^{\mathrm{b}} \pm 0.16$ & $11.34^{\mathrm{a}} \pm 0.15$ & $12.47^{\mathrm{a}} \pm 1.17$ & 0.006 \\
Hue angle & $19.51^{\mathrm{a}} \pm 0.21$ & $35.38^{\mathrm{b}} \pm 0.10$ & $23.77^{\mathrm{a}} \pm 0.28$ & $<0.0001$ \\
$\begin{array}{l}\text { Saturation index } \\
\text { (chroma) }\end{array}$ & $17.41^{\mathrm{b}} \pm 0.81$ & $17.39^{\mathrm{b}} \pm 0.54$ & $22.03^{\mathrm{a}} \pm 0.65$ & $<0.0007$ \\
\hline
\end{tabular}

Superscripts of the same letter in each row did not differ significant $(\mathrm{p}>0.05), \mathrm{T}_{1}=$ Six month age, $\mathrm{T}_{2}=$ Nine month age and $\mathrm{T}_{3}=$ Twelve month age.

\section{CONCLUSION}

It is revealed from the study that 12 months of slaughter age showed better in terms of productive and meat quality traits which is proven from carcass traits, proximate components, physicochemical traits, sensory attributes and instrumental color values. Therefore, 12 months of age may be recommended as optimum slaughter age for Jamuna basin lambs.

\section{ACKNOWLEDGEMENT}

The authors are highly appreciated to the Krishi Gobeshana Foundation (KGF) for funding this research project.

\section{REFERENCES}

Ali, M.M., Hossain, M.M., Akhter, S., Islam, M.S. and Hashem, M.A. (2013). Effect of age on slaughterhouse by-products of indigenous cattle of Bangladesh. Bangladesh Journal of Animal Science, 42(1): 62-66.

AOAC. (2005). Association of Official Analytical Chemists, Official method of analysis, $18^{\text {th }}$ Ed. Washington, D.C.

Berihulay, H., A. Abied, X. He, L. Jiang, and Y. Ma (2019). Adaptation mechanisms of small ruminants to environmental heat stress. Animals, 9: 75

Choi, M.J., Abduzukhurov, T., Park, D.H., Kim, E.J. and Hong, G.P. (2018). Effects of deep freezing temperature for long-term storage on quality characteristics and freshness of lamb meat. Korean Journal of Food Science of Animal Resources, 38: 959-969.

CIELAB. (2014). A guide to understand color communication. Retrieved from www.xrite.com 
Cirne, L.G.A., da Silva Sobrinho, A.G., de Oliveira, E.A., Jardin, R.D., Junior, A.S.V., de Carvalho, G.G.P., Jaeger, S.M.P.L., Bagaldo, A.R., de Almeida, F.A., Endo, V., Moreno, G.M.B. and de Lima Valenca, R. (2018). Physicochemical and sensory characteristics of meat from lambs fed diets containing mulbery hay. Italian Journal of Animal Science, 17:621-627.

Claffey, N.A., Fahey, A.G. Gkarane, V., Moloney, A.P., Monahan, F.J. and Diskin, M.G. (2018). Effect of breed and castration on production and carcass traits of male lambs following an intensive finishing period. Translational Animal Science, 2: 407-418.

Costa, R.G., Cartaxo, F.Q., Santos, N.M. and Queiroga, R.C.R.E. (2011). Preliminary study on meat quality of goats fed levels of licury oil in the diet. Asian-Australasian Journal of Animal Science, 24(8): 1112-1119.

Gashu, M., Urge, M., Animut, G. and, Tadesse, D. (2017). Slaughter performance and meat quality of intact and castrated Washera sheep kept under feedlot condition. African Journal Agricultural Research, 12: 3072-3080.

Haque, M.I., Sarder, M.J.U., Islam, M.A., Khaton, R., Islam, M.H. and Hashem, M.A. (2020). Morphometric characterization of Barind sheep of Bangladesh. Journal of Earth and Environmental Science, 4: 192.

Hashem, M.A., Hossain, M.M., Rana, M.S., Islam, M.S. and Saha, N.G. (2013). Effect of heat stress on blood parameter, carcass and meat quality of Black Bengal goat. Bangladesh Journal of Animal Science, 42: 57-61.

Hashem, M.A., Islam, T., Hossain, M.A., Kamal, M.T., Sun, M.A. and Rahman, M.M. (2020). Production performance of Jamuna basin lamb under semi-intensive management system in Bangladesh. Journal of Animal and Veterinary Advances, 19 (11):150-158.

Hosain, M.I., Rahman, M.H., Hossain, M.M., Akhter, S., Hashem, M.A., Rahman, S.M.E. and Deog-Hwan, O. (2015). Effect of age and primal cuts on beef quality of indigenous cattle. Journal of Meat Science and Technology, 3(2):18-27.

Hossain, M.A., Islam, M.A., Akhtar, A., Islam, M.S. and Rahman, M.F. (2018a). Socioeconomic status of sheep farmers and the management practices of sheep at Gafargaon Upazila of Mymensingh district. International Journal of Natural and Social Sciences, 5(4): 07-15.

Hossain, M.A., Akhtar, A., Easin, M., Maleque, M.A., Rahman, M.F. and Islam, M.S. (2018b). Women household livelihood improvement through sheep (Ovis aries) rearing in Sirajganj district of Bangladesh. International Journal of Natural and Social Sciences, 5(3): 1-8.

Hossain, M.A., Sun, M.A., Islam, T., Rahman, M.M., Rahman, M.W. and Hashem, M.A. (2021). Socio-economic characteristics and present scenario of sheep farmers at Sherpur district in Bangladesh. SAARC Journal of Agriculture, 19(1): 185-199.

Huque, K.S., Sultana, N., Rahman, M.Z. and Hossain, S.M.J. (2007). Effect of age on feed utilization for growth performance and carcass quality in native bulls. Progressive Agriculture, 18: 107-116.

Jahan I., Haque, M.A., Hashem, M.A., Rima, F.J., Akhter, S. and Hossain, M.A. (2018). Formulation of value-added beef meatballs with Pomegranate (Punica granatum) 
extract as a source of natural antioxidant. Journal of Meat Science and Technology, 6(1):12-18.

Kopuzlu, S., Esenbuga, N., Onenc, A., Macit, M., Yanar, M., Sadrettin Yuksel, S., Ozluturk, A. and Unlu, N. (2018). Effects of slaughter age and muscle type on meat quality characteristics of Eastern Anatolian Red bulls. Archives Animal Breeding, 61: 497-504.

Mancini, R. and Hunt, M. (2005). Current research in meat color. Meat Science, 71:100-121.

Moniruzzaman, M., Hashem, M.A., Akhter, S. and Hossain, M.M. (2002). Effect of different feeding systems on carcass and non-carcass parameters of Black Bengal goat. Asian Australasian Journal of Animal Sciences, 15(1): 61-65.

Murshed, H.M., Sarker, M.A.H., Rahmana, S.M.E. and Hashem, M.A. (2014). Comparison of carcass and meat quality of Black Bengal goat and indigenous sheep of Bangladesh. Journal of Meat Science and Technology, 2: 63-67.

Pethick, D.W., Hopkins, D.L., D’Souza, D.N., Thompson, J.M. and Walker, P.J. (2005). Effects of animal age on the eating quality of sheep meat. Australian Journal of Experimental Agriculture, 45: 491-498.

Polidori, P., Pucciarelli, S., Gammertoni, N. and Polzonetti, V. (2017). The effect of slaughter age on carcass and meat quality of Fabrianese lambs. Small Ruminant Research, 155:12-15.

Rahman, M.F., Iqbal, A., Hashem, M.A. and Adedeji, A.A. (2020). Quality assessment of beef using Computer Vision Technology. Food Science of Animal Resources, 40(6): 896-907.

Rajkumar, V., Verma, A.K., Ramachandran, N. and Pal, S. (2017). Carcass traits and meat quality characteristics and fatty acid profile of Barbari goats as influenced by castration and slaughter age. Indian Journal of Animal Science, 87: 1149-1154.

Rana, M.S., Hashem, M.A., Sakib, M.N. and Kumar, A. (2014). Effect of heat stress on blood parameter in indigenous sheep. Journal of Bangladesh Agricultural University, 12(1): 91-94.

Rashid, M.M., Hossain, M.M., Azad, M.A.K. and Hashem, M.A. (2013). Long term cyclic heat stress influences physiological responses and blood characteristics in indigenous sheep. Bangladesh Journal of Animal Science, 42: 96-100.

Saba, N.A., Hashem, M.A., Azad, M.A.K., Hossain, M.A. and Khan, M. (2018). Effect of bottle gourd leaf (Lagenaria siceraria) extract on the quality of beef meatball. Bangladesh Journal of Animal Science, 47(2): 105-113.

Sarker, A.K., Amin, M.R., Hossain, M.A., Ali, M.S. and Hashem, M.A. (2017). Present status of organic sheep production in Ramgoti Upazila of Lakshmipur district. Journal of Environmental Science and Natural Resources, 10: 95-103.

Sultana, N., Hossain, S.M.J., Chowdhury, S.A., Hassan, M.R. and Ershaduzzaman, M. (2010). Effect of age on intake, growth, nutrient utilization and carcass characteristics of castrated native sheep. The Bangladesh Veterinary, 27: 62-73.

Sun, M.A., Hossain, M.A., Islam, T., Rahman, M.M., Hossain, M.M. and Hashem, M.A. (2020). Different body measurement and body weight prediction of Jamuna basin sheep in Bangladesh. SAARC Journal of Agriculture, 18(1): 183-196. 
Watanabe, G., Motoyama, M., Nakajima, I. and Sasaki, K. (2018). Relationship between water-holding capacity and intramuscular fat content in Japanese commercial pork loin. Asian-Australasian Journal of Animal Science, 31(6): 914-918.

Worku, A., Urge, M., Animut, G. and Asefa, G.G. (2020). Comparative slaughter performance and meat quality of Rutana, Gumuz and Washera sheep of Ethiopia supplemented with different levels of concentrate. Open Journal of Animal Sciences, 10: 48-63. 